\title{
Simulation of Transit Transportation along the Northern Sea Route under Climate Change
}

\author{
D. O. Eliseev ${ }^{a}, b, *$ and Yu. V. Naumova ${ }^{c}$ \\ ${ }^{a}$ Russian New University, Moscow, 105005 Russia \\ ${ }^{b}$ Federal Research Center "Subtropical Scientific Center,” Russian Academy of Sciences, Sochi, 354002 Russia \\ ${ }^{c}$ Federal Research Center "Computer Science and Control", Russian Academy of Sciences, Moscow, 119333 Russia \\ *e-mail: elisd@mail.ru
}

Received November 3, 2020; revised November 12, 2020; accepted November 19, 2020

\begin{abstract}
The article examines the problems and development prospects for the international transit of goods along the NSR. The existing restrictions on increasing freight traffic up to 80 million tons per year declared in program documents are identified. An option for its enhancement based on the domestic fleet of Arctic cargo ships is proposed. The article summarizes the main shortcomings of earlier studies assessing the transit capabilities of the NSR. A model for assessing the optimal number of ships for the transportation of goods is proposed taking into account climatic, physical-geographical, technological, and temporal constraints and risks. Within the framework of the model, the cost of goods transportation was estimated for implementing two scenarios of transit traffic.
\end{abstract}

Keywords: NSR, transit traffic, container ships, climatic changes, ice conditions, model, scenarios, costs, efficiency

DOI: $10.1134 / \mathrm{S} 1075700721020040$

Experience in estimating freight trafic along the NSR: results and limitations. The Decree of the President of the Russian Federation dated May 7, 2018, No. 204 On national Goals and Strategic Objectives for the Development of the Russian Federation for the Period up to 2024 determined that by 2024 the volume of cargo transportation along the Northern Sea Route (hereinafter referred to as the NSR) was to be brought up to 80 million tons per year [1]. This is a serious challenge, given that the Soviet period of operation was 6.5 million tons in 1987, not to mention the reform period of the 1990s, when traffic volumes dropped to 1.5 million tons by 1998 and the period 1998-2010 when it was about two million tons a year [2, 3].

Forecast estimates of freight traffic by 2024 are different (Table 1). According to official estimates of 2018-2019 (optimistic forecast), the total traffic volume may reach 92.6 million tons, of which the transportation of LNG and gas condensate will account for 44\%. At the same time, despite the current and expected improvement of the ice situation in the coming decade due to climate change in the Arctic [4], experts express serious doubts about such volumes of cargo transportation, pointing out the absence of a cargo base [5]. Thus, coal mining projects in Taimyr, which had been supposed to make up $25 \%$ of the cargo traffic, were postponed indefinitely and the commissioning of the capacities for the production of LNG and oil production was partially shifted for several later years. Even with the implementation of the planned investment projects for LNG (46 million tons) and oil production (25 million tons), it is not possible to achieve the planned volumes.

In recent years, the NSR has been considered mainly as an internal transport system, which is the only route that ensures the delivery of vital goods to the regions of the Far North (northern delivery) and contributes to the prompt development of the resource potential of the Russian Arctic. However, the focus on domestic use does not exclude the possibility of developing international transit of goods between Europe and Asia.

Currently, the volume of transit traffic along the NSR is insignificant. The accumulated transit volume for the period 2010-2019 is about 5\% of the total volume of cargo transportation along the NSR. At the same time, it is impossible to be sure that the transit cargo volume will progressively grow. The highest value of transportation volume was attained in 2013 and amounted to 1.3 million tons.

In recent years, the utilization of the transit capacity of the NSR has sharply decreased. Back in 2017, large international transport companies Cosco and Maersk declared a significant increase in freight traffic up to 12 million tons by 2028 , followed by a rise to 28 million tons [8]. However, the difficult geopolitical 
Table 1. Forecast of freight traffic along the NSR by 2024, thousand tons

\begin{tabular}{l|c|c|c}
\hline \multirow{2}{*}{ Freight traffic structure } & \multirow{2}{*}{2019 (fact) } & \multicolumn{2}{|c}{2024} \\
\cline { 3 - 4 } & & negative scenario & optimistic scenario \\
\hline Liquefied natural gas and gas condensate & 19614.7 & 35500 & 41000 \\
Oil and petroleum products & 8162.9 & 9250 & 17100 \\
Other cargo and transit & 3465.7 & 3500 & 11500 \\
Coal, ore & 288.0 & 1000 & 23000 \\
Total & 31531.3 & 49250 & 92600 \\
\hline
\end{tabular}

Source: the authors' calculations based on data [5-7].

and world economic situation significantly complicates plans to attract international freight carriers. However, the complex geopolitical and world economic situation significantly complicates plans to attract international carriers. Some transport companies have already questioned the possibility of using the NSR, on the declared grounds of environmental, climatic, and other risks [9]. The actual volumes of the current transit correspond more to the scale of testing the NSR than to the full-scale use of the route.

A number of studies of the last decade have proven the attractiveness of the NSR as an alternative transit route between Europe and Asia [10-13]. Scenario calculations by various authors show that the cost and speed of goods delivery from Europe to Asia and back using the northern route can be reduced by $30 \%$, depending on the simulation parameters. The main drawback of previous studies is the assessment of transportation in a case study format, assuming different modes of transportation, including the use of several types of ships; at the same time, in the process of modeling, a simultaneous assessment of transportation by one ship along different routes is carried out depending on seasonality, fuel price, and other components. Such studies are valuable for transport companies and ship-owners, as their results make it possible for the latter to correctly verify the cost indicators. However, in order to assess the possibilities of full loading for the NSR from the viewpoint of freight traffic, this approach seems to be somewhat simplified, since it does not take into account a number of fundamental circumstances.

For example, some authors focus on assessing the cost of transportation of bulk and liquid cargo, which seems to be not entirely correct since the main transit traffic between European and Asian countries is represented by container transportation of finished products, and not raw materials and semifinished goods. Thus, the bulk of Asian cargo (over 600 million tons) passing through the Suez Canal is transported in containers. In the opposite direction, equipment, cars, etc. are transported, which is also container-type cargo. That is why, in the last decade, large-tonnage container ships have been commissioned, which can carry more than 15000 containers (TUE-15000) in one voyage.

In addition, individual researchers often compare vessels of different tonnage when assessing the cost of cargo transportation and conclude that the competitiveness of the NSR is decreasing, since during a certain period of time it is possible to carry less cargo through it than through the Suez Canal. In [14], it is noted that only appropriate to compare directly the competitiveness of vessels of different carrying capacity if a set of equivalent conditions is met. For example, the TUE- 15000 container carrier is more efficient than the TUE-4500 when timely and fully loaded and has the appropriate travel speed. Otherwise, its competitiveness is reduced. This is especially evident in the current context of a decrease in world trade due to the coronavirus pandemic, geopolitical tensions between trading partners, and others.

An earlier study [8] proves that the most rational option for the development of international transit along the NSR is the construction of a domestic Arctic container fleet, which will be able to ensure the transportation of containers independent of international transport companies. This option is in good agreement with the NSR development program in terms of strengthening the role of the Arctic fleet. Taking this into account, it is advisable to propose a model and, on its basis, to assess the prospects for the development of international transit along the NSR relying on the domestic fleet of Arctic container ships.

The proposed methodological approach and initial data for modeling the transit freight traffic along the NSR. The purpose of the simulation is to estimate the required number of vessels for the transit transportation of containers along the NSR between Europe (Rotterdam) and Asia (Yokohama), which is based on the following initial assumptions.

Firstly, the target function is not the development of the Arctic fleet and not the maximization of revenues from transportation but an increase in the cargo base of the NSR to 80 million tons annually and more, which implies the need for transit freight traffic in the amount of at least 10 million tons (Table 1). Accordingly, priority in calculations is given to assessing the 
required number of vessels, the maximum possible annual number of shipments, and the degree of loading for each vessel, rather than the profitability of the traffic. The economic assessment is based on the cost of transporting one unit of cargo (20-foot container).

Secondly, it is assumed that the fleet of Arctic container carriers will be initially designed and built taking into account the harsh Arctic conditions, despite the effects of global warming and a reduction in the ice area, since the ice coverage and the complexity of the route remain significant due to the increase in the number of icebergs [15]. In September 2020, the Rules of Navigation along the NSR [16] were adjusted, according to which independent annual navigation of Arc4-Arc9 class vessels is allowed along the entire length of the route, regardless of ice conditions.

In this connection, the optimal solution would be to create ice-class Arc9 container ships, capable of year-round independent navigation and free from restrictions on ice conditions. However, the implementation of such a project involves technological difficulties. Only over the last five years, work has been started on the design of medium-tonnage container ships TUE-4000 of ice class Arc5-Arc7, while the tanker fleet of such vessels has been operating for about 10 years. Actually, there are several high-iceclass container ships of small capacity currently in operation [17]. Taking into account the lack of projects for the creation of large-capacity container ships of enhanced ice class and restrictions on the annual operation of vessels, the object of modeling was Arc7 ice-class container ships with a capacity of TUE-4500, which can be operated on the route all year round with periodic drawing of icebreaker support during especially dangerous periods of navigation.

Third, an important modeling factor is assessing the natural and climatic conditions of transportation along the NSR. At different times of the year and within seasons, the characteristics of ice along the route change, which affects the speed of goods delivery as well as the number of vessels required for achieving the target parameters of cargo turnover.

The distance of goods transportation between the two selected reference ports of Rotterdam in Europe and Yokohama in Japan along the NSR is $13600 \mathrm{~km}$. At the same time, to assess the speed of ships depending on the season and climatic conditions, it is advisable to divide the specified route into several sections (Table 2).

The average speed of a container ship with a capacity of TUE-4500 in ordinary water is about 20 knots $(37 \mathrm{~km} / \mathrm{h})$; in an ice field, the speed decreases depending on the specific ice situation. Due to the fact that the use of large-tonnage ships along the NSR began relatively recently (in 2015-2016), there is still no accumulated objective representative statistics on the speed of movement during the ice period. Thus, in 2019, the Arc7 ice-class gas carrier Vladimir Rusanov
Table 2. Geographic characteristics of the route along the NSR

\begin{tabular}{c|l|r}
\hline № & \multicolumn{1}{|c|}{ Geographic localization } & $\begin{array}{c}\text { Distance, } \\
\mathrm{km}\end{array}$ \\
\hline 1. & Rotterdam-Murmansk & 2800 \\
2. & Murmansk-Kara Strait & 900 \\
3. & Kara Strait-Bering Strait, & 5600 \\
& including: & \\
3.1. & Kara Strait & 33 \\
3.2. & Kara Sea(western part) & 900 \\
3.3. & Kara Sea (eastern part) & 700 \\
3.4. & Vilkitsky Strait & 130 \\
3.5. & Laptev sea & 1100 \\
3.6. & Sannikov Strait & 238 \\
3.7. & East Siberian Sea & 1400 \\
3.8. & Long Strait & 128 \\
3.9. & Chukchi sea & 971 \\
4. & Bering Strait-Petropavlovsk-Kamchatsky & 2390 \\
5. & Petropavlovsk-Kamchatsky-Yokohama & 191 \\
& & 13600 \\
\hline
\end{tabular}

Source: compiled by the authors.

Table 3. The speed of a container ship TUE-4500 depending on the state of the water area (navigation mode)

\begin{tabular}{l|c|c}
\hline \multirow{2}{*}{ Natural and climatic conditions } & \multicolumn{2}{|c}{ Vessel speed } \\
\cline { 2 - 3 } & knots & $\mathrm{km} / \mathrm{h}$ \\
\hline Ice-free water & 20.0 & 37.0 \\
Light ice conditions & 14.9 & 27.5 \\
Average ice conditions & 12.0 & 22.2 \\
Severe ice conditions & 8.9 & 16.5 \\
\hline
\end{tabular}

passed the ice part of the NSR in July in 6 days, leaving the port of Sabetta, and earlier the same route was covered in 9 days [18].

During the May period, the Christophe de Margerie gas carrier covered the specified distance in 12 days [19]. The May period is considered more difficult in comparison with July in terms of ice conditions (see Table 4). At the same time, the average speed of a gas carrier is lower than the speed of container ships, therefore, for the purposes of modeling, a table was compiled that reflects the speed characteristics of vessels along the entire route, depending on the natural and climatic conditions (Table 3 ) compiled by the authors based on data from [14, 20].

The ice situation on the NSR is a seasonal factor and it changes significantly every year. With regard to the transport accessibility of the NSR, a reduction in 
Table 4. Ice conditions on the NSR in 2015 and 2019

\begin{tabular}{|c|c|c|c|c|c|c|c|c|c|c|}
\hline \multirow{2}{*}{ Month } & \multicolumn{2}{|c|}{ Kara Sea (West) } & \multicolumn{2}{|c|}{ Kara Sea (East) } & \multicolumn{2}{|c|}{ Laptev sea } & \multicolumn{2}{|c|}{ East-Siberian Sea } & \multicolumn{2}{|c|}{ Chukchi sea } \\
\hline & 2015 & 2019 & 2015 & 2019 & 2015 & 2019 & 2015 & 2019 & 2015 & 2019 \\
\hline January & $A$ & $L$ & $S$ & $L$ & $S$ & $A$ & $S$ & A & $\mathrm{L}$ & $\mathrm{L}$ \\
\hline February & $\boldsymbol{A}$ & $L$ & $T$ & $\boldsymbol{A}$ & $T$ & $A$ & A & A & A & A \\
\hline March & A & A & $\mathrm{S}$ & $\mathrm{S}$ & S & S & $\mathrm{S}$ & $\mathrm{S}$ & $S$ & S \\
\hline April & $S$ & $A$ & $\mathrm{~S}$ & $\mathrm{~S}$ & S & S & $\mathrm{S}$ & $\mathrm{S}$ & $\mathrm{S}$ & S \\
\hline May & $S$ & $A$ & $\mathrm{~S}$ & $\mathrm{~S}$ & $\mathrm{~S}$ & $\mathrm{~S}$ & $\mathrm{~S}$ & $\mathrm{~S}$ & $\mathrm{~S}$ & $\mathrm{~S}$ \\
\hline June & $\mathrm{I}-\mathrm{F}$ & $\mathrm{I}-\mathrm{F}$ & $\boldsymbol{A}$ & $\boldsymbol{L}$ & $\boldsymbol{A}$ & $L$ & S & $\mathrm{S}$ & $\mathrm{L}$ & $\mathrm{L}$ \\
\hline July & $\mathrm{I}-\mathrm{F}$ & $\mathrm{I}-\mathrm{F}$ & $\mathrm{I}-\mathrm{F}$ & $\mathrm{I}-\mathrm{F}$ & $\mathrm{I}-\mathrm{F}$ & $\mathrm{I}-\mathrm{F}$ & $\boldsymbol{L}$ & $A$ & $\mathrm{I}-\mathrm{F}$ & $\mathrm{I}-\mathrm{F}$ \\
\hline August & $\mathrm{I}-\mathrm{F}$ & $\mathrm{I}-\mathrm{F}$ & $\mathrm{I}-\mathrm{F}$ & $\mathrm{I}-\mathrm{F}$ & $\mathrm{I}-\mathrm{F}$ & $\mathrm{I}-\mathrm{F}$ & $\mathrm{I}-\mathrm{F}$ & $\mathrm{I}-\mathrm{F}$ & $\mathrm{I}-\mathrm{F}$ & $\mathrm{I}-\mathrm{F}$ \\
\hline September & $\mathrm{I}-\mathrm{F}$ & $\mathrm{I}-\mathrm{F}$ & $\mathrm{I}-\mathrm{F}$ & $\mathrm{I}-\mathrm{F}$ & $\mathrm{I}-\mathrm{F}$ & $\mathrm{I}-\mathrm{F}$ & $\mathrm{I}-\mathrm{F}$ & $\mathrm{I}-\mathrm{F}$ & $\mathrm{I}-\mathrm{F}$ & $\mathrm{I}-\mathrm{F}$ \\
\hline October & $\mathrm{I}-\mathrm{F}$ & $\mathrm{I}-\mathrm{F}$ & $\mathrm{L}$ & $\mathrm{L}$ & $\mathrm{L}$ & $\mathrm{L}$ & $\mathrm{L}$ & $\mathrm{L}$ & $\mathrm{I}-\mathrm{F}$ & $\mathrm{I}-\mathrm{F}$ \\
\hline November & $\mathrm{L}$ & $\mathrm{L}$ & $\mathrm{L}$ & $\mathrm{L}$ & $A$ & $L$ & $\mathrm{~L}$ & $\mathrm{~L}$ & $\mathrm{~L}$ & L \\
\hline December & A & $\mathrm{L}$ & A & $\mathrm{L}$ & S & A & A & $\mathrm{L}$ & A & A \\
\hline
\end{tabular}

Symbols denoting types of ice conditions: S-severe; A-average; L-light; I-F-ice-free water.

Source: compiled by the authors based on the data of the meteorological base of the Arctic and Antarctic Research Institute // http://www.aari.ru/main.php?lg=0\&id=17.

the area and thickness of ice means an increase in the average speed and eliminating the need for using use icebreaker support, which reduces the cost of transportation and shortens the time of goods delivery. According to the RCP 8.5 global climate change scenario developed by the International Panel of Experts on Climate Change (IPCC) and assuming the most radical warming by 2099 , the total ice area in the Arctic macro-region will not exceed 500000 square kilometers, having decreased by more than an order of magnitude compared to the level of 2019 (5.8 million square kilometers). In 2035, the predicted ice area will be reduced to four million square kilometers [21].

The dynamics of reduction are most clearly manifested during the period of winter-spring navigation in the waters of the Kara Sea and the Laptev Sea, where in just the last five years (2015-2020) the ice situation has significantly improved (in Table 4 this area is highlighted in bold italics). This ensures the possibility of full-fledged navigation along the NSR in a year-round mode in ice-free water as early as by 2040 .

The climate forecast, based on the available data on the gradual reduction in the ice area from year to year, is designed for a long-term perspective (usually 50 years). At the same time, economic calculations and assessments are based on the short and medium term (up to 10 years), less often the long term (20-25 years), based on the investment payback period. Therefore, taking into account climatic circumstances, the model uses data on ice conditions for 2019 without comparison with previous periods, assuming that in the medium and long term, ice conditions in the studied region of the Arctic Ocean will be comparable to 2019 or better.

According to Table 5 [22], in the period from January to May, ice conditions in certain sections of the route require the use of icebreakers to escort ships, while the speed of ships is significantly reduced. This affects both the time (terms) and the cost of transporting goods.

Taking into account the above data, the time of the vessel travel along the NSR is calculated by the formula

$$
T_{n s r}=S_{i} D_{i}+t_{p}
$$

where $T_{n s r}$ is time of the goods transportation along the route; $i$ denotes the sequence number of the route part; $S_{i}$ stands for the speed of the vessel in the $i$ th section of the route; $D_{i}$ is the length of the $i$ th section of the route; and $t_{p}$ is the total time of the vessel staying in ports along the route.

The model scheme of cargo transportation provides for two scenarios of transit flows along the NSR-international and Arctic.

The international scenario assumes year-round transit transportation of goods by Arctic-class ships directly between the two end points of the routeRotterdam and Yokohama. This scenario involves the risks of potential downtime of these vessels in ports due to the temporary absence or delay of cargo there, as well as increased transportation costs due to the higher fuel consumption of Arctic-class vessels compared to conventional vessels. At the same time, there is no dependence on third carriers and cargo owners, there is no need to develop a specialized transport and logistics infrastructure for servicing containerized cargo in northern ports.

In the Arctic scenario, Arctic-class ships are involved in transportation along the NSR to the extreme large ports (Murmansk, Petropavlovsk-Kamchatsky) where cargo will be transshipped to ordinary ships. At the same time, the speed of cargo delivery is 
Table 5. Methodology for calculating the economic efficiency of container transportation along the NSR

\begin{tabular}{|c|c|c|}
\hline Cost item & Calculation methodology & Note \\
\hline $\begin{array}{l}\text { Capital expendi- } \\
\text { tures }\end{array}$ & $A_{e}=(C-S) / t(2)$ & $\begin{array}{l}A_{e}-\text { annual capital cost estimate; } C-\text { capital costs of building the vessel; } \\
S-\text { sale price for disposal (metal price * weight); } t \text {-operating time ( } 25 \text { years). }\end{array}$ \\
\hline Insurance & $I=0.00343^{*} C+N S R_{p}(3)$ & $\begin{array}{l}I-\text { insurance cost; } 0.343 \% \text { of the value of the vessel; } C \text {-capital costs of } \\
\text { building a ship; } N S R_{p}-\text { Northern allowance }\end{array}$ \\
\hline $\begin{array}{l}\text { Repair and ser- } \\
\text { vice }\end{array}$ & $R M=0.01095^{*} C(4)$ & $\begin{array}{l}R M-\text { cost of the ship repair and maintenance; } 1.095 \% \text { of the vessel value } \\
C-\text { capital costs of building a ship }\end{array}$ \\
\hline Salary & $\begin{array}{l}\text { Salary } 100000-130000 \\
\text { a month }\end{array}$ & Average value 115000 USD a month \\
\hline $\begin{array}{l}\text { Fuel consump- } \\
\text { tion }\end{array}$ & $F=f_{c r}^{t} t^{*} p_{f}(5)$ & $F$-fuel cost; $f_{c r}^{t}$-specific fuel consumption per day; $t$-time; $p_{f}$-fuel price \\
\hline Port dues & $P_{d}=0.428 * G T(6)$ & $\begin{array}{l}P_{d}-\text { port dues; } 0,428 \text { USD per unit of ship's gross tonnage; } G T \text {-gross ton- } \\
\text { nage of the vessel; }\end{array}$ \\
\hline $\begin{array}{l}\text { Icebreaker sup- } \\
\text { port }\end{array}$ & $\operatorname{Tr}_{f}=G T^{*} T_{a r c} * Z_{n o}(7)$ & $\begin{array}{l}T r_{f}-\text { icebreaker support cost; } G T \text {-gross tonnage of the vessel; } T_{a r c}-\text { ice- } \\
\text { breaker support rate per unit of the ship's gross tonnage; } Z_{n o}-\text { number of } \\
\text { icebreaker escort zones }\end{array}$ \\
\hline
\end{tabular}

In general terms, the calculation formula is as follows: $S c=A_{e}+I+R M+$ Salary $+F+P_{d}+T_{f}(8)$

Sources: compiled by the authors based on the data of [20, 23-25].

increasing due to the reduction in the ship downtime, as well as high turnover, Russian ports are becoming well-developed logistics hubs for servicing containers. In addition, it becomes possible to load vessels with domestic cargo. At the same time, there are risks associated with the unwillingness of "ordinary" carriers to deliver goods only to Murmansk and to Petropavlovsk-Kamchatsky.

Assessing the economic efficiency of transit traffic is based on the generally accepted approach, which includes estimating the totality of capital, operating and transport costs (Sc) (see Table 5).

Capital expenditures. As mentioned earlier, so far there has been no practical experience in the construction and operation of TUE-4500 container ships of the Arc7 class, however, the design of such vessels is already underway. Taking this circumstance into account, the model calculations were based on preliminary estimates of the cost of building such ships and existing close analogies, which makes it possible to obtain the desired price reference. According to the available estimates, the cost of one vessel similar to the abovementioned Arc7 class ranges from 85 to 180 million dollars $[23,26]$. In this work, the cost of one Arc7 class container ship is determined at 130 million USD.

Operating costs. Operating costs include insurance, crew salaries based on the results of calculations carried out in the studies $[14,20]$. The insurance coverage is $0.343 \%$ of the average vessel value a year. Crew salaries range from $\$ 100000$ USD to 130000 USD monthly, or an average of 115000 USD. In addition, this category of costs includes the cost of annual main- tenance and repair, which is $1.095 \%$ of the average vessel value.

Transport costs. Transport costs are variable and depend on the speed of the vessel, the number of ports where it goes to replenish supplies and transshipment of cargo, the number of containers on the vessel, and the time of using icebreakers on the way. In order to calculate the actual data on transport costs, the data of works $[20,23-24]$ were used. At the same time, the average fuel consumption throughout the entire route was assumed to be $78.76 \mathrm{t} /$ day, based on the fact that in ice conditions the speed decreases but the fuel consumption for overcoming ice increases, and when sailing in clean water, both the ship's speed and consumption increase. Harbor dues in Russian and international ports amount to $0.428 \mathrm{USD} / \mathrm{t}$ of the vessel's gross tonnage [27, 28]. The cost of icebreaker support is determined based on the established tariffs of the NRS administration [25], according to which this cost for ships of the ice class Arc7 in the summer-autumn navigation period is $2.91-5.83 \mathrm{USD} / \mathrm{t}$ of gross tonnage, depending on the range of icebreaker support, and in the winter-spring navigation period, 7.2214.44 USD.

Scenario-based assessment of transit freight trafic along the NSR. In accordance with the calculation methodology proposed above, let us first consider the transport characteristics of transit, including an estimate of the maximum number of voyages per year, the maximum possible volumes of cargo traffic as well as the required number of vessels in accordance with the assumed scenarios (Table 6). 
Table 6. Results of scenario modeling of transportation time along the NSR

\begin{tabular}{|c|c|c|c|c|c|c|c|c|c|c|}
\hline \multicolumn{11}{|c|}{ International scenario * } \\
\hline $\begin{array}{l}\text { Time intervals/ } \\
\text { Route points }\end{array}$ & 1 & 2 & 3 & 4 & 5 & 6 & 7 & \multirow[t]{2}{*}{ ports } & \multirow[t]{2}{*}{ Days on the way } & \multirow{2}{*}{$\begin{array}{l}\text { Average number } \\
\text { of voyages a month }\end{array}$} \\
\hline Distance, $\mathrm{km}$ & 3700 & 933 & 700 & 1230 & 1638 & 1099 & 4300 & & & \\
\hline \multicolumn{11}{|c|}{ Days on the way by months, including: } \\
\hline January & 4 & 1.4 & 1.1 & 2.3 & 3.1 & 1.7 & 5 & 5 & 23.6 & 1.3 \\
\hline February & 4 & 1.4 & 1.3 & 2.3 & 3.1 & 2.1 & 5 & 4 & 23.2 & 1.2 \\
\hline March & 4 & 1.8 & 1.8 & 3.1 & 4.1 & 2.8 & 5 & 5 & 27.6 & 1.1 \\
\hline April & 4 & 1.8 & 1.8 & 3.1 & 4.1 & 2.8 & 5 & 4 & 26.6 & 1.1 \\
\hline May & 4 & 1.8 & 1.8 & 3.1 & 4.1 & 2.8 & 5 & 5 & 27.6 & 1.1 \\
\hline June & 4 & 1.1 & 1.1 & 1.9 & 4.1 & 1.7 & 5 & 4 & 22.9 & 1.4 \\
\hline July & 4 & 1.1 & 0.8 & 1.4 & 3.1 & 1.2 & 5 & 5 & 21.6 & 1.4 \\
\hline August & 4 & 1.1 & 0.8 & 1.4 & 1.8 & 1.2 & 5 & 4 & 19.3 & 1.6 \\
\hline September & 4 & 1.1 & 0.8 & 1.4 & 1.8 & 1.2 & 5 & 4 & 19.3 & 1.6 \\
\hline October & 4 & 1.1 & 1.1 & 1.9 & 2.5 & 1.2 & 5 & 4 & 20.8 & 1.5 \\
\hline November & 4 & 1.4 & 1.1 & 1.9 & 2.5 & 1.7 & 5 & 4 & 21.6 & 1.4 \\
\hline December & 4 & 1.4 & 1.1 & 2.3 & 2.5 & 2.1 & 5 & 5 & 23.4 & 1.3 \\
\hline \multicolumn{10}{|c|}{ Total number of voyages per year } & 16 \\
\hline \multicolumn{10}{|c|}{ Total transported cargo per vessel ( 72000 containers) } & $1440000 \mathrm{t}$ \\
\hline
\end{tabular}

\begin{tabular}{|c|c|c|c|c|c|c|c|c|c|c|}
\hline \multicolumn{11}{|c|}{ Arctic scenario $* *$} \\
\hline $\begin{array}{l}\text { Time intervals/ } \\
\text { Route points }\end{array}$ & 1 & 2 & 3 & 4 & 5 & 6 & 7 & \multirow[t]{2}{*}{ Ports } & \multirow[t]{2}{*}{ Days on the way } & \multirow{2}{*}{$\begin{array}{l}\text { Average number } \\
\text { of voyages a month }\end{array}$} \\
\hline Distance, $\mathrm{km}$ & 900 & 933 & 700 & 1230 & 1638 & 1099 & 2390 & & & \\
\hline \multicolumn{11}{|c|}{ Days on the way by months, including: } \\
\hline January & 1 & 1.4 & 1.1 & 2.3 & 3.1 & 1.7 & 3 & 3 & 15.6 & 2 \\
\hline February & 1 & 1.4 & 1.3 & 2.3 & 3.1 & 2.1 & 3 & 2 & 15.2 & 1.8 \\
\hline March & 1 & 1.8 & 1.8 & 3.1 & 4.1 & 2.8 & 3 & 3 & 19.6 & 1.6 \\
\hline April & 1 & 1.8 & 1.8 & 3.1 & 4.1 & 2.8 & 3 & 2 & 18.6 & 1.6 \\
\hline May & 1 & 1.8 & 1.8 & 3.1 & 4.1 & 2.8 & 3 & 3 & 19.6 & 1.6 \\
\hline June & 1 & 1.1 & 1.1 & 1.9 & 4.1 & 1.7 & 3 & 2 & 14.9 & 2.1 \\
\hline July & 1 & 1.1 & 0.8 & 1.4 & 3.1 & 1.2 & 3 & 3 & 13.6 & 2.2 \\
\hline August & 1 & 1.1 & 0.8 & 1.4 & 1.8 & 1.2 & 3 & 2 & 11.3 & 2.8 \\
\hline September & 1 & 1.1 & 0.8 & 1.4 & 1.8 & 1.2 & 3 & 2 & 11.3 & 2.7 \\
\hline October & 1 & 1.1 & 1.1 & 1.9 & 2.5 & 1.2 & 3 & 2 & 12.8 & 2.4 \\
\hline November & 1 & 1.4 & 1.1 & 1.9 & 2.5 & 1.7 & 3 & 2 & 13.6 & 2.2 \\
\hline December & 1 & 1.4 & 1.1 & 2.3 & 2.5 & 2.1 & 3 & 3 & 15.4 & 2 \\
\hline \multirow{2}{*}{\multicolumn{10}{|c|}{$\begin{array}{l}\text { Total number of voyages per year } \\
\text { Total transported cargo per vessel } 112.5 \text { thousand containers }\end{array}$}} & 25 \\
\hline & & & & & & & & & & $2250000 \mathrm{t}$ \\
\hline \multicolumn{5}{|c|}{ *International scenario: } & \multicolumn{6}{|c|}{ **Arctic scenario } \\
\hline \multicolumn{5}{|c|}{$\begin{array}{l}\text { 1-Rotterdam-Kara Strait } \\
\text { 2-Kara Sea (West) } \\
\text { 3-Kara Sea(East) } \\
\text { 4-Laptev sea } \\
\text { 5-East Siberian Sea } \\
\text { 6-Chukchi sea } \\
\text { 7-Bering Strait-Yokohama }\end{array}$} & \multicolumn{6}{|c|}{$\begin{array}{l}\text { 1-Murmansk-Kara Strait } \\
\text { 2-Kara Sea (West) } \\
\text { 3-Kara Sea (East) } \\
\text { 4-Laptev sea } \\
\text { 5-East Siberian Sea } \\
\text { 6-Chukchi sea } \\
\text { 7-Bering Strait-Petropavlovsk-Kamchatsky }\end{array}$} \\
\hline
\end{tabular}

Source: the authors' calculations. 
Table 7. Estimation of the cost of goods transportation along the NSR

\begin{tabular}{l|c|c|c}
\hline \multirow{2}{*}{ Indicator } & \multirow{2}{*}{$\begin{array}{c}\text { Norma- } \\
\text { tive } \\
\text { meanings }\end{array}$} & $\begin{array}{c}\text { International, } \\
\text { USD/voyage }\end{array}$ & $\begin{array}{c}\text { Arctic, } \\
\text { USD/voyage }\end{array}$ \\
\cline { 3 - 4 } & & 295000.0 & 188800.0 \\
Capital expenditures (per vessel), million USD & 130 & 33442.5 & 21403.2 \\
Insurance (rate in \% of the vessel value) & 0.4 & 88968.8 & 56940.0 \\
Repair and maintenance (rate, in \% of the vessel value) & 1.1 & 86250.0 & 55200.0 \\
Crew salary, million USD/year & 1.38 & 537537.0 & 370487.0 \\
Fuel cost (t/day),USD & 27566 & 43417.0 & 43417.0 \\
Port dues (two ports), USD & 21708.5 & 219415.9 & 157333.7 \\
Icebreaker support cost (zones per gross tonnage), USD & 921116.3 & 1304031.2 & 893580.9 \\
Total expenses & & 289.8 & 198.6 \\
Per unit of cargo (container TUE-20) & &
\end{tabular}

Source: the authors' calculations.

Within the international scenario, the transport scheme assumes that container ships are used yearround (365 days a year), while five days a year are spent on servicing and maintenance of ships. Downtime at each port of loading/unloading is two days. One vessel will be able to make a maximum of 16 voyages on the Rotterdam-Yokohama-Rotterdam route, taking into account the downtime for servicing and transshipment at ports: nine voyages during the summer-autumn navigation period (June-November), seven during the winter-spring period (DecemberMay), since the most severe ice conditions in the eastern part of the Kara Sea, as well as along the entire length of the NSR further to the East, occur in the spring. At the same time, the most favorable ice situation for the speed of the ships is observed from July to October, when water is ice-free all along almost the entire route (see Table 4).

In this scenario, a container ship TUE-4500 of the Arctic class Arc7 with a 100 percent load in both directions can annually transport 72000 containers, which is equivalent to 1.44 million tons of transported cargo. Thus, to ensure a cargo traffic of 10 million tons or more, at least seven vessels are required.

The transport scheme of the Arctic scenario also provides for the year-round use of ships, with five days of maintenance and repair, the downtime in each port is one day, due to the absence of downtime during unloading/loading cargo due to the need for further transshipment of cargo. One vessel can make a maximum of 25 voyages on the Murmansk-PetropavlovskKamchatsky-Murmansk route: 12 voyages during the summer-autumn navigation period, nine voyages during the winter-spring navigation. One vessel can make a maximum of 25 voyages on the MurmanskPetropavlovsk-Kamchatsky-Murmansk route: 12 voyages during the summer-autumn navigation period, and nine voyages during the winter-spring navigation. The total annual volume of transported goods will amount to 1.89 million tons annually. Consequently, to ensure a cargo traffic of 10 million tons or more, at least five ships are needed.

Further, following the adopted calculation methodology, we will consider the economic efficiency of goods transportation along the NSR based on the annual costs per vessel. Data for both scenarios are summarized in Table 7.

These data demonstrate the comparability of the annual costs of goods transportation under the two scenarios, despite the abovementioned differences. Each vessel is used year-round; therefore, the expenditure side remains the same. The difference lies in the volume of goods transported between the end points of the route and, accordingly, in the cost of transportation per unit of cargo. At the same time, the relative reduction in the cost of transportation in the Arctic scenario when calculating transportation costs along the Murmansk-Petropavlovsk-Kamchatsky route simultaneously increases the total cost of delivery to the final port due to additional transshipment costs. Therefore, the model considers the average estimate of the actual costs per voyage.

According to model calculations, in the Arctic scenario, the turnover of ships is 1.5 times higher than in the international scenario. Owing to this, a reduction in the cost of transportation per unit of cargo is achieved.

Conclusions. From the economic viewpoint, for Russia, the Arctic scenario is optimal, as it is more profitable in terms of the cost of transportation and the number of vessels required for its implementation (five units). However, the advantage obtained in scenario calculations is not so obvious after detailed analysis. When this scenario is implemented, the state needs to concentrate the necessary resources in order to create two multifunctional ports at the extreme points of the NSR (Murmansk, Petropavlovsk-Kamchatsky), 
which will be able to receive container ships of any class, provide a full range of relevant logistics services at competitive prices, and ensure attractiveness for international transport companies.

With a slight loss in the cost of transporting, the route through the Suez Canal (for more details see [14]), in which for modeling large-capacity container ships TUE-15000/TUE-20000 were used with a gross tonnage 3-4 times higher than that of TUE-4500, which naturally leads to a decrease in the cost of transporting a unit of cargo), the NSR, nevertheless, is very attractive in terms of the speed of goods delivery. This circumstance is especially important when transporting "critical cargo," for which the priority is the speed of delivery, and not the cost of transportation. In addition, in recent years, a serious rethinking has been required for considering the expediency of using largetonnage container ships designed for a significant volume of cargo traffic. Due to the instability of the global economy in the medium term, a decrease in the volume of world cargo turnover is possible, which will require a new look at logistic operations. Smaller vessels can become more attractive due to prompt loading (filling with cargo) and, accordingly, higher transport turnover.

\section{FUNDING}

Estimates and calculations of climatic and physical-geographical data in the article were supported by the Russian Foundation for Basic Research (project no. 20-5575002BF_t Coastal OceAn SusTainability in Changing Climate (COAST); scenario modeling of cargo traffic, economic assessment of the efficiency of cargo transportation, including taking into account climatic changes, were supported by the Russian Foundation for Basic Research, project no. 19-01000675 "Program-target management of the transport infrastructure of the Arctic zone of the Russian Federation").

\section{ACKNOWLEDGMENTS}

The authors are grateful to Academician of the Russian Academy of Sciences B.N. Porfiriev for valuable comments and suggestions in the preparation of the article.

\section{CONFLICT OF INTEREST}

The authors declare that they have no conflicts of interest.

\section{REFERENCES}

1. Decree of the President of the Russian Federation of May 7, 2018 No. 204 "On National Goals and Strategic Objectives of the Development of the Russian Federation for the Period up to 2024. https://base.garant.ru/71937200/. Accessed October 20, 2020.

2. A. I. Timoshenko, "The Arctic and the Northern Sea route in the Soviet state strategy," Sev. Reg.: Nauka, Obraz., Kul’t., Nos. 2-4, 16-20 (2015).
3. V. N. Polovinkin and A. B. Fomichev, "Prospective directions and problems of the development of the Arctic transport system of the Russian Federation in the XXI century," Arkt.: Ekol. Ekon., No. 3, 74-83 (2012).

4. A. V. Yulin, N. A. Vyazigina, and E. S. Egorova, "Interannual and seasonal variability of the ice area in the Arctic Ocean according to satellite observations," Ross. Arkt., No. 7, 28-40 (2019). https://doi.org/10.24411/2658-4255-2019-10073

5. Rosatom Proposed to Reduce Forecast for Cargo Volume in the Arctic by 25\%. https://www.rbc.ru/business/10/09/2020/5f589b189a794752254570fb.

6. Ministry of Transport Expects Sharp Increase in Freight Traffic along the Northern Sea Route in 2024. https://neftegaz.ru/news/transport-and-storage/477823mintrans-ozhidaet-rezkogo-rosta-gruzopotoka-posevernomu-morskomu-puti-v-2024-g/.

7. Development of Ports in the Russian Arctic. https://morproekt.ru/articles/prezentatsii/1161-2020.

8. D. O. Eliseev and Yu. V. Naumova, "Problems and prospects for the development of international transit along the Northern Sea Route," Federalizm, No. 3, 35-50 (2019).

https://doi.org/10.21686/2073-1051-2019-3-35-50

9. The Largest Container Carrier from France Refused to Use the Northern Sea Route. https://www.kommersant.ru/doc/4072383.

10. M. Furuichi and N. Otsuka, "Proposing a common platform of shipping cost analysis of the Northern Sea Route and the Suez Canal Route," Marit. Econ. Logist. 17, 9-31 (2015). https://doi.org/10.1057/mel.2014.29

11. Socio-Economic Development of the Russian Arctic in the Context of Global Climate Change, Ed. by B. N. Porfir'ev (Nauchn. Konsul't., Moscow, 2017) [in Russian].

12. J. Verny and C. Grigentin, "Container shipping on the Northern Sea Route,” Int. J. Prod. Econ. 122 (1), 107117 (2009). https://doi.org/10.1016/j.ijpe.2009.03.018

13. M. Liu and J. Kronbak, "The potential economic viability of using the Northern Sea Route (NSR) as an alternative route between Asia and Europe," J. Transp. Geogr. 18 (3), 434-444 (2010).

https://doi.org/10.1016/j.jtrangeo.2009.08.004

14. Masahiko Furuichi and Natsuhiko Otsuka, "Examining quick delivery at an affordable cost by the NSR/SCR-combined shipping in the age of Megaships," Marit. Policy Manage. 45 (8), 1057-1077 (2018). https://doi.org/10.1080/03088839.2018.1473656

15. S. V. Pisarev, Northern Sea Route. Oceanologist's View. Part II. https://goarctic.ru/work/sevmorputvzglyad-okeanologa-chast-ii/. Accessed October 20, 2020.

16. Decree of the Government of the Russian Federation of September 18, 2020 No. 1487 "On Approval of the Navigation Rules in the Water Area of the Northern Sea Route." http://publication.pravo.gov.ru/Document/View/ 0001202009220024.

17. Annual Report of PJSC MMC Norilsk Nickel for 2019. https://ar2019.nornickel.ru/business-overview/transportation-assets. 
18. Liquefied Gas Tanker Vladimir Rusanov Set a New Record for the Time to Pass the Northern Sea Route. https://neftegaz.ru/news/transport-and-storage/476939tanker-gazovoz-vladimir-rusanov-ustanovil-novyy-rekord-po-vremeni-prokhozhdeniya-smp/. Accessed October 20, 2020.

19. For the First Time in History, Gas Carrier Passes the NSR in May. https://teknoblog.ru/2020/06/01/105796.

20. Shengda Zhu, Xiaowen Fu, Adolf K. Y. Ng, Meifeng Luo, and Ying-En Ge, "The environmental costs and economic implications of container shipping on the Northern Sea Route,” Marit. Policy Manage. 45 (4), 456-477 (2018). https://doi.org/10.1080/03088839.2018.1443228

21. V. P. Meleshko, V. M. Kattsov, A. V. Baidin, T. V. Pavlova, and V. A. Govorkova, "Expected change of hydrologic cycle in Northern Eurasia due to disappearance of multiyear sea ice in the Arctic Ocean," Russ. Meteorol. Hydrol. 41, 735-746 (2016).

22. M. Stopford, Maritime Economics, 2nd ed. (Taylor \& Francis e-Library, 2003). http://csinvesting.org/wpcontent/uploads/2016/05/Maritime-Economics.pdf.

23. Hua Xu, Dong Yang, and Jinxian Weng, "Economic feasibility of an NSR/SCR-combined container service on the Asia-Europe lane: A new approach dynamically considering sea ice extent," Marit. Policy Manage. 54
(4), 514-519 (2018). https://doi.org/10.1080/03088839.2018.1443521

24. Y. Zhang et al., "Shipping efficiency comparison between Northern Sea Route and the conventional AsiaEurope shipping route via Suez Canal," J. Transp. Geogr. 57, 241-249 (2016). https://doi.org/10.1016/j.jtrangeo.2016.09.008

25. Order of the Federal Tariff Service of Russia No. 45-T / 1 of 04.03.2014 "On Approval of Tariffs for Icebreaker Assistance of Vessels Provided by FGUP Atomflot in the Water Area of the Northern Sea Route." https://legalacts.ru.

26. Shipping Insight. Drewry Maritime Research (2015). https://www.drewry.co.uk/maritime-research-products/maritime-research-products/shipping-insightannual-subscription.

27. General Terms and Conditions Including Port Tariffs. https://www.portofrotterdam.com/sites/default/files/ general-terms-and-conditions-including-port-tariffs2020.pdf?token=ItqGenYF.

28. Port Dues and Tariffs. https://www.rosmorport.ru/filials/ppv_portcharges/.

Translated by I. Pertsovskaya 